\title{
Workers' participation in regional economic change following establishment closure
}

\author{
Lars-Fredrik Andersson • Therese Danley • \\ Rikard Eriksson • Martin Henning
}

Accepted: 13 February 2018/Published online: 14 April 2018

(C) The Author(s) 2018

\begin{abstract}
This article analyses if and when workers affected by economic destruction in the form of establishment closures move to more productive or newly started establishments in the region, become selfemployed, leave the region or become displaced. Results from multinominal probit models show that the majority of these workers face destructive employment outcomes from a Schumpeterian point of view compared to a matched sample of workers not subject to a closure. However, we do find indications of a creative destruction as a small, albeit significant, share become employed in young establishments. Different types of human capital influence the likelihood of triggering positive or negative regional outcomes. While higher education significantly decreases the risk for unemployment, high-income earners more often become engaged in creative outcomes. Firm tenure increases the likelihood of becoming employed in younger establishments.
\end{abstract}

L.-F. Andersson $(\bowtie) \cdot$ T. Danley $\cdot$ R. Eriksson

Department of Geography and Economic history, Umeå University, SE-901 87 Umea, Sweden

e-mail: lars-fredrik.andersson@umu.se

T. Danley

e-mail: therese.danley@umu.se

R. Eriksson

e-mail: rikard.eriksson@umu.se

\section{Henning}

School of Economics, Business and Law, University of Gothenburg, Gothenburg, Sweden

e-mail: martin.henning@handels.gu.se
There are significant spatial differences where metropolitan regions excel as loci of creative change, whereas smaller and peripheral regions face far less creative outcomes of economic transformation.

Keywords Creative destruction - Establishment closure $\cdot$ Worker reallocation · Regional transformation

JEL classification $\mathrm{R} 11 \cdot \mathrm{J} 63 \cdot \mathrm{L} 26$

\section{Introduction}

The Schumpeterian tradition of economic research suggests that the destruction of firms and industries is necessary to enable growth of new innovative and more productive firms. In this view, the process of economic evolution is one of the 'creative destructions' (Schumpeter 1939). This study traces how human capital resources, made redundant through destruction may, or may not, find new 'creative' uses in regional economies. Our interest in this particular issue is motivated by the fact that the reallocation of workers to new productive activities in regions is a crucial mechanism of regional change.

The empirical analysis is based on matched employer-employee data for Sweden between 1995 and 2006. Our main sample includes all workers leaving closing establishments in the period 2000-2003. We first assess the type of labour market activity workers subject to a closure are engaged in compared to a matched sample of workers not experiencing a closure. Since all workers 
who are affiliated with closing establishments in any of the 5 years before closure are included, we can make a distinction between early and late leavers. The timing and selection into employment outcomes are therefore analysed in a second step. Third, we investigate how particular groups of workers, with various forms of human capital, differ in how they potentially become engaged in creative change in the regional economy after redundancy.

The study contributes to the existing literature in three principal regards. We contribute to the redundancy and displacement literature by differentiating not only between those who gain re-employment or not following redundancy, but also in which types of activities. To the entrepreneurship literature, we show the extent to which workers engage in successful entrepreneurial efforts following establishment closures. Lastly, we assess to what extent and by whom localised human capital is re-bundled into new formations following redundancies and how this is positioned into a larger macro-scale picture of regional convergence and divergence.

Section 2 provides a review of the key literature on the topic. In the third section, the data and empirical issues are accounted for. Section 4 provides the empirical results, and Section 5 concludes.

\section{Establishment closure and creative destruction in regional economies}

A core message underpinning the Schumpeterian idea of creative destruction is that certain mechanisms are essential for avoiding regional demise in times of economic transformation. Regions must realise the reallocation of resources to new, more innovative and more productive activities. In trying to ascertain which activities are most suitable, or at least most likely, for growth, economic geographers have championed the idea of novel 'rebundling' (or recombination) of local resources (Bathelt and Boggs 2003; Boschma and Martin 2010). In fact, recent contributions in the literature concerned with regional economic resilience argue that recombining partly existing resources is essential to achieve sustained growth (Boschma 2015). In this context, it has been found that new activities related to previously existing production are far more likely to enter regional economies and that new activities to a large extent depend on existing resources arranged in new combinations (Boschma and Frenken 2011; Neffke et al. 2011; Boschma et al. 2013; He et al. 2016).

Human capital is a key resource in such processes of transformation. The labour displacement literature (e.g. Fallick 1996) provides an individual perspective on how human capital is re-used (or not) in new combinations, and it has repeatedly been found that most workers affected by closedowns or major layoffs find new employment shortly after leaving the dispatching firm. Taking this to a regional level, an evolving literature merging economic geography with aspects of labour economics takes an interest in how, and under which circumstances, redundant workers find new employment in regions (Holm et al. 2016; Eriksson et al. 2016; Neffke et al. 2016; Hane-Weijman et al. 2017). These studies could be viewed from a Schumpeterian perspective, where crises such as major closures resulting in the loss of less productive firms are inevitable and even necessary to allow for the growth of more productive firms. This presumes that most redundant workers will move on to new jobs with higher wages in more productive firms that expand. This reasoning leads us to formulate our first, rather optimistic, hypothesis:

H1. Establishment closures should induce, on average, creative changes in regions.

However, even if a majority of redundant workers are normally re-employed quickly, individual-level studies have shown other effects where some redundant workers tend to face high adjustment costs such as wage loss and skill obsolescence (e.g. Jacobson et al. 1993; Gripaios and Gripaios 1994; Tomaney et al. 1999; Bailey et al. 2012; Ohlsson and Storrie 2012). Such effects are of course essential from the individuals' viewpoint but tells less about which workers leaving exiting firms have a higher likelihood of participating in processes of regional creative destruction (see Huttunen et al. 2006). There are however some recent attempts to explain not only how workers leaving exiting firms find new productive uses for their individual human capital, but also in which types of activities. Huttunen et al. (2011), for example, find that a large part of displaced workers find employment in the same two-digit industry in the short-run and that these workers are driving the process of creative destruction within industries. This is particularly true for the less educated part of the workforce while highly educated workers are more likely to find new employment in other industries. 
For Schumpeter, the entrepreneur was a principal agent of change, realizing new productive combinations of resources in a competitive environment (Schumpeter 1934). The empirical results on the relationship between layoffs and new firm formation however remain rather inconclusive (e.g. Armington and Acs 2002; Ritsilä and Tervo 2002; Lee et al. 2004; Sutaria and Hicks 2004; Fritsch and Falck 2007; Audretsch et al. 2015). One reason is that entrepreneurship may be the outcome of countervailing push and pull factors. On the one hand, factors on the push-side are circumstances where individuals are forced into entrepreneurship due to negative labour prospects such as unemployment or low-paid wage work (Carrasco, 1999; Ritsilä and Tervo 2002; Parker 2009). On the other hand, motives to set up a firm in order to take advantage of a market situation may be regarded as opportunity driven, such as commercialisation of an innovation, investing personal savings or utilizing abundant human capital (Bates 1991; Acs and Armington 2006).

Interestingly, a recent study from Sweden shows that business cycles did not act as a major trigger for startups, but human capital was more decisive, giving rise to a propitious selection into self-employment (Svaleryd 2015). Additionally, proponents of the 'heritage theory' emphasise the importance of pre-entry experience for the success of entrepreneurs (Buensdorf and Klepper 2009). This line of reasoning leads us to the formulation of a second hypothesis:

H2. Formal human capital (education) and experience increase the chance of redundant workers becoming engaged in creative change.

Whether workers who leave plants that are downsizing are triggering creative changes may also be related to the point in time when workers are leaving the closing firm. Several years before closure, firms tend to have lower levels of productivity (Griliches and Ragev 1995; Pike 2005) and their employment growth decreases (Almus 2004). The dynamics that arise from within-firm restructuring, in turn, affect the downsizing strategies of the firm, the evolving composition of workers and workers' decisions to stay or leave. The shrinking of the workforce occurs through layoffs and voluntary choices by the workers, but it could be expected that workers leaving earlier in the process have had time to search for alternative employment and leave voluntarily while those remaining later in the closing process have a higher probability of encountering forced displacement. There is evidence that the separation of workers during the dismantling process does not occur in a random way, as shown in the case of a manufacturing plant in the Netherlands where younger and less experienced workers left earlier in the process of decline and a disproportionate number of workers with longer tenure and higher salaries stayed until the end (Pfann and Hamermesh 2008; see also Huttunen et al. 2006 for Norway). Schwerdt (2011), however, found in the Austrian context that the age of the workforce decreased gradually over several years and the average earnings of the workforce decreased the year before closure. While the specific effects vary depending on place and industry, it is reasonable to expect that the opportunities for early and late leavers to find new productive uses for their human capital may differ substantially (Eliasson and Storrie 2006; Pfann and Hamermesh 2008; Holm et al. 2016). Institutional factors likely play a role in the outcomes, and Sweden's employment protection and welfare system could affect the strategies of firms and workers during the dismantling process (Eliasson and Storrie 2006). This leads us to the formulation of our final hypothesis:

H3. Workers leaving closing establishments early are more likely to participate in creative regional change compared to late leavers.

\section{Empirical strategy}

Our approach emphasises how the reallocation of workers impacts the region and who participates in creative regional change. It is not designed to follow the direct effects of establishment closure at the individual level. ${ }^{1}$ To empirically study a given worker's participation in regional change following establishment closure, we use matched employer-employee data made available by Statistics Sweden. Individuals and establishments have anonymised identification numbers which allows us to follow them over time in the database.

A standard conception of positive change in economies is when higher productivity is achieved. But from a Schumpeterian perspective, activities that introduce

\footnotetext{
${ }^{1}$ The concept of 'participation' is inspired by March and Simon
} (1958). 
variety and new experiments in regional economies are also important (Frenken et al. 2007; Neffke et al. 2014). These two pathways of creative change can be conceptualised as either introducing (via entrepreneurship) or reinforcing (by starting work in more productive establishments ${ }^{2}$ or in young establishments) more competitive or novel economic activities.

To track the participation of the workers in regional change, we specify seven outcomes which reflect different employment statuses for all workers leaving closing establishments. The outcomes are defined by the labour market activity of the worker the year after leaving an establishment. This approach of decomposing labour flows into post-displacement activities is inspired by the displacement literature (Huttunen et al. 2006; Frederiksen and Westergaard-Nielsen 2007), and in this study, we characterise the labour flows by establishment type and characteristics.

First, we define outcomes which we regard as signalling creative regional change after destruction. The data do not include a measure for labour productivity. Therefore, we use median wage of the establishments as a proxy for labour productivity at the establishment level as income tends to be regarded as a robust proxy for productivity (Feldstein 2008). To assess participation in already existing but more productive establishments, which reinforce competitive structures, we identify workers who become:

1. employed in the same region in an establishment with higher median wage than in the previous establishment.

Participation in activities which introduce new organisational experiments to the region, in a way that promises creation, is by us taken to be defined by workers who become either:

2. self-employed in an establishment in a traded industry ${ }^{3}$ in the region, which survives at least 3 years, or

\footnotetext{
${ }^{2}$ Establishment is interchangeable with firm in case of a single establishment firm. We control for multiestablishment status in the regressions.

${ }^{3}$ We use the definition of traded industries employed in Neffke et al. (2018): Swedish Standard Industrial Classification (SNI) codes 1500 3999 (manufacturing), 6500-6999 (finance and insurance), 7200-7399 (computer services, R\&D) and 7400-7499 (other business services). The reason for this is that firms in traded industries normally have demand and competition structures which transcend regional markets, making firms in these industries particularly interesting and likely to contribute to regional exports.
}

3. employed in a newly started establishment in the region (young establishments), which survives at least 3 years from when the worker entered the establishment.

The start-up of new establishments in traded industries, surviving more than 3 years, represents a new and arguably competitive entrepreneurial effort. ${ }^{4}$ The rationale for choosing a 3-year window of survival is that establishments which remain after the fierce selection process during the first years of formation tend to be resilient (Borggren et al. 2016). Taken together, new and young establishments have the potential to contribute positively to the renewal of business structures in regions (Klepper 2002). If establishments do not fit this criterion, the worker is placed accordingly in the other outcomes.

Participation in less creative processes is on the other hand represented by labour market outcomes after redundancy that signal less positive impacts on regional economies. The first one of these is given as a contrast to outcome (1) above, when workers become:

4. employed in the same region in an establishment with lower median wage than in the previous establishment.

In contrast to the positive entrepreneurial outcome in (2), we also define an outcome where the workers become:

5. self-employed in an establishment in a non-traded industry in the region, which survives 3 years or more.

We regard (5) as a less positive regional outcome than (2), as it takes place in a non-traded industry which to a larger extent rely on local demand. Lastly, we distinguish between two outcomes, which from a regional point of view represent either a loss of human capital or that regional human capital resources are left completely idle, including when workers either:

6. leave the region and move to a different region (regional migration), or

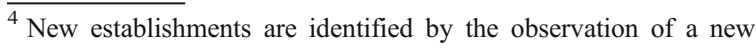
establishment ID number, which is defined by Statistics Sweden.
} 
7. become and stay unemployed or enter early retirement.

All workers in our sample who do not directly fall under categories 1-6 are placed in category 7 .

We take a number of measures to reduce potential noise in our estimations. Spurious closures are controlled for, meaning that establishments that disappear or change due to mergers and acquisitions are not included in the closure group nor are establishments that reassign their workforce within the same establishment. We omit all single-person workplaces and all workplaces younger than 10 years. The rationale for this is that we only wish to include observations that (i) influence many employees and (ii) that are established and not part of the normal turnover (i.e. many new firms exit within a year) in the economy. Also, the data is restricted to workers between the ages of 20 and 60 years, measured by when the worker left the closing establishment. The closer to retirement (65 years of age in the Swedish case) workers are, the more likely that some arrangements are made which facilitate a transition to early retirement. Workers who are retired their final year at the establishment, defined by if they receive more retirement income than work income, are removed, as are individuals with missing variables on establishment, sector and income.

Our main sample of workers subjected to a closure thus consists of those individuals who were employed in establishments in Sweden that closed between 2000 and 2003. In total, 21,414 establishments closed during this period at a rather even yearly rate (about 7100 a year). Figure 1 illustrates total employment in the selected closing establishments from 10 years prior to closure until the closing year (index), aggregated by region. We use three regional groups based on the 72 functional labour market regions (this functional regional division based on commuting distances is set to capture the distance within which a worker can find new work without having to change region of residence) defined by the Swedish Agency for Economic and Regional Growth. These are 'metropolitan' regions (Stockholm, Gothenburg and Malmö), 'large regional centres' (university regions often housing regional public administration bodies) and any of the other 'smaller regions' in Sweden. It is evident that the slopes do not differ extensively, but the closure process in general is more incremental outside the metropolitan regions and steeper in the metropolitan regions. Sectoral differences are however slightly greater (not reported). Establishments in the service sectors face a shorter process than manufacturing establishments, which partly explain the regional differences as manufacturing establishments tend to be relatively more concentrated outside the largest regions. Guided by Fig. 1, we start to follow the labour market outcomes of workers 5 years before the closing year of the establishment ( $\mathrm{t}$ ).

Often, job separation can be considered endogenous to later job choices and success (Jacobson et al. 1993; Schwerdt 2011). To further control for the effect of selfselection into job separation and reduce the dependence of leaving a closing establishment on the workers' characteristics, we compare the workers of closing establishments to workers who leave surviving establishments during the same study period. ${ }^{5}$ We apply exact matching and propensity score matching, inspired by Neffke et al. (2016), to develop a counterfactual sample.

Exact matching is performed on the year the worker left the establishment, and the propensity score is predicted using a probit model regressing on a set of preseparation variables. Apart from individual variables such as age and sex known to influence labour market outcomes (Fallick 1996; Neffke et al. 2016), our dataset allows us to observe characteristics like the education level (bachelor's degree or higher), tenure (time in same establishment as proxy for establishment-specific knowledge), sector experience (time in same four-digit industry prior to leaving the establishment as proxy for industry-specific knowledge) and income (to proxy unobserved skills). Since the likelihood of creative change induced by redundant workers may also be influenced by plant and regional characteristics (Hane-Weijman et al. 2017), we apply matching on firm size and industry specialisation (absolute number of regional establishments in a given fourdigit industry). Additionally, the income trends are particularly interesting as they capture workers' unobserved ability. Following Neffke et al. (2016), workers' income every year 6 years prior to leaving the establishment to 2 years prior and the log of income growth between 5 and 2 years prior to leaving the establishment are also included in the propensity score matching. We use the nearest neighbour method without replacement,

\footnotetext{
${ }_{5}^{5}$ Descriptives (not reported) reveal that closing establishments, to a slightly higher degree than surviving establishments, tend to be smaller and in service industries, mainly located in any of the three metropolitan regions.
} 
Fig. 1 The process of downsizing. Own elaborations on data from Statistics Sweden

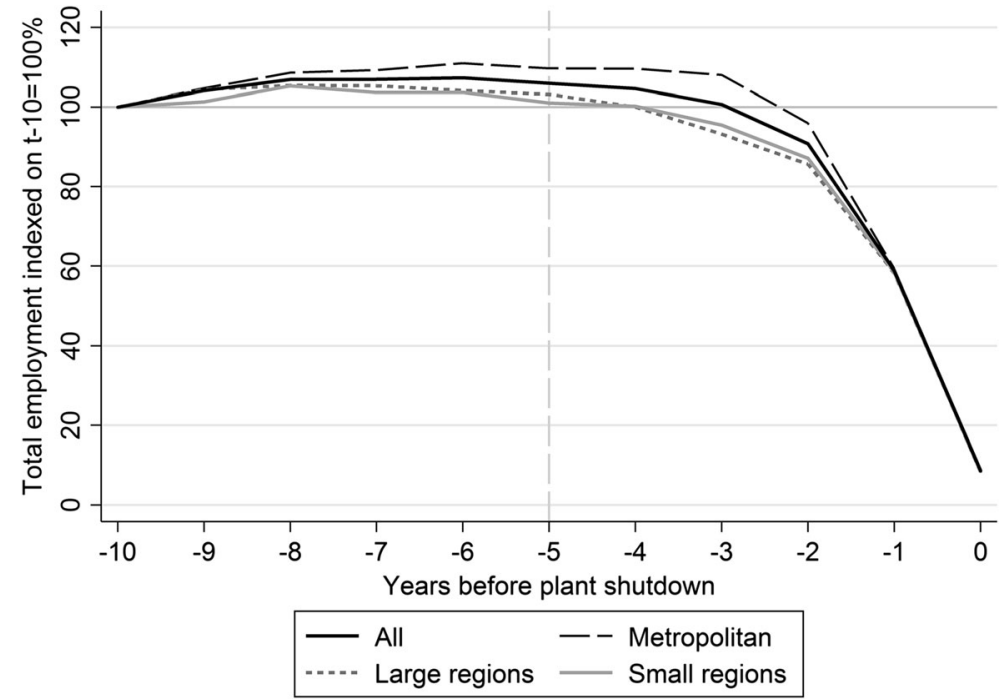

a calliper of 0.02 and discard the unused observations in the end. To construct a balanced model, balance diagnostics were performed by checking the difference between unmatched and matched standard differences and the variance ratios (Austin 2007; Ho et al. 2007). Figure 2 displays the standardised differences of means before and after the matching procedure, comparing the characteristics of the workers leaving closing plants to others. After matching, the differences in means are reduced considerably, with all variables below the common 0.1 threshold (see Austin 2011). Our final sample includes 273,257 workers leaving closing establishments and an equal number representing a counterfactual group who were not working at a closing plant but otherwise have similar characteristics.

\section{Results}

4.1 Who participates in regional creative destruction after establishment shutdown?

We estimate a series of multinominal probit models with a categorical variable representing each of the seven different outcomes defined in Section 3. Table 1 displays two different models on the same dependent variable. In the first model (A), we include a dummy capturing whether the worker has been subject to a closure or not (Exit), while the second model (B) distinguishes between early leavers ( $\mathrm{t}-5$ to $\mathrm{t}-2)$ and late leavers (t-1 to t0). Apart from variables on human capital, tenure, experience and income mentioned above, we add a set of conventional individual controllers, as well as establishment-, industry- and region-specific controllers (see table note and Appendix Table 3 for detailed definitions and description). Since the control variables show the average influence of each variable on respective outcome (irrespective of exit or non-exit), we do not present these variables. To reduce the impact of unobserved variation that might influence the results, we use fixed effects (dummies) for each two-digit NACE-category and for each year a given worker leaves an establishment. All models are estimated with cluster-robust standard errors at the establishment level (Cameron and Trivedi 2010). ${ }^{6}$ Due to the large sample size, statistical significance tends to be easily obtained although the economic effect is negligible. Therefore, average marginal effects are reported where one unit change in each variable can be interpreted as the change in percentage points on the likelihood of transitioning to a given outcome.

On average, there is little evidence supporting our first hypothesis that the closure of old activities

\footnotetext{
${ }^{6}$ Furthermore, we tested various indicators of regional unemployment (both at the time the worker left and a 5 year average prior to leaving the establishment), regional share of small businesses ( $<10$ employees) and the growth (decline) of the establishment. In general, unemployment had no significant influence on the likelihood of finding new employment but increased the risk of leaving the region or entering unemployment, while the share of small businesses had a minor influence on entrepreneurship. However, when introducing the fixedeffects, neither of these variables were significant while the individuallevel variables remained robust. These additional regional-specific variables were therefore omitted from the final version.
} 
Fig. 2 Plotted standardised difference of means before and after matching (c.f., Austin 2011). Own elaborations on data from Statistics Sweden

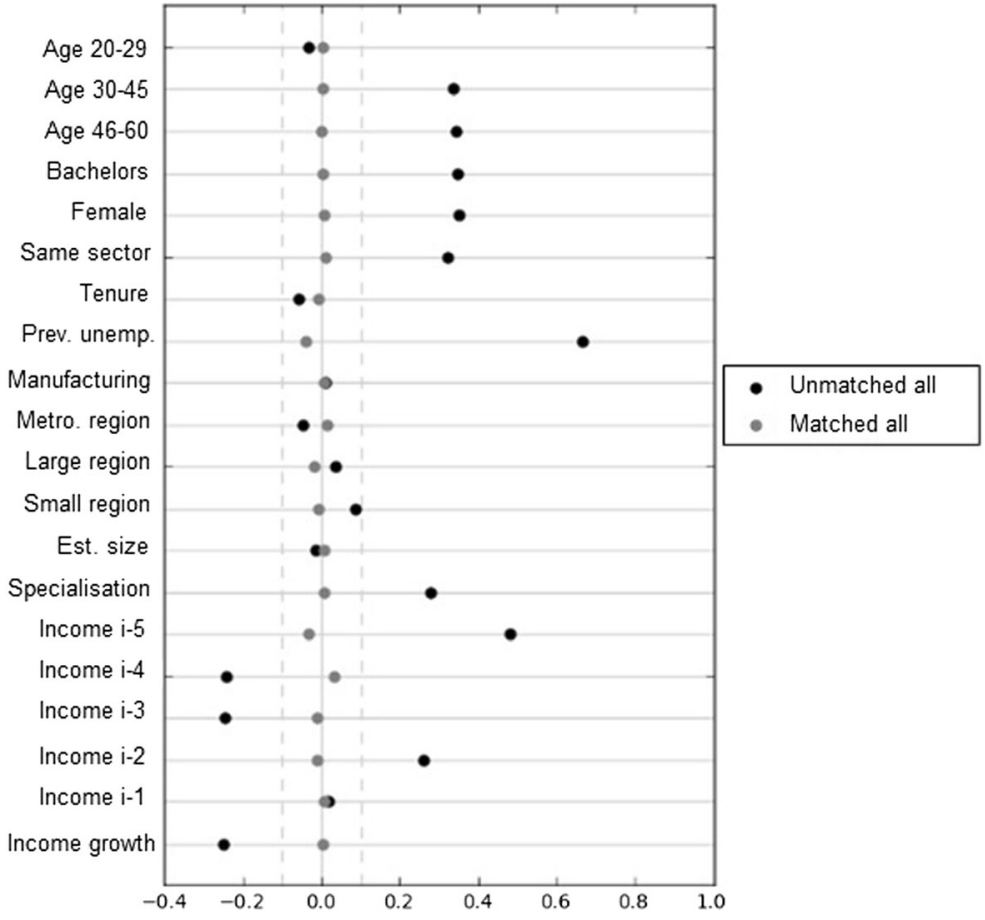

reinforces more competitive or creative regional structures. Based on Table 1, workers leaving closing establishments are less likely to find new employment in incumbent establishments regardless of productivity (models 1A and 4A), less likely to become entrepreneurs (2A and $5 \mathrm{~A})$ and less likely to leave the region (6A). Also, the greatest effect is associated to the no work outcome, as closure workers are about 19 percentage points more likely to be out of work compared to non-closures. Hence, redundant workers are, on average, more likely to be unemployed in the same region than workers not subject to a closure. Only in one aspect do the results indicate that the closure of establishments triggers some creative outcomes in regions compared to the reference group: closure workers are more likely to start working in a young establishment (3A).

We do not find any support for the fact that there would be major differences in outcomes between early and late leavers as suggested in hypothesis 3 . The sign and significance of both early and late are similar to the exit variable reported in A, except for the fact that only the late leavers are more likely to make the transition to young establishments. A clear pattern emerges from the effect sizes. Again, late leavers in general are less likely to trigger a positive regional change compared to early leavers. The negative effect of making a move to a high- wage establishment (1B) is higher for late leavers as is the risk for unemployment (7B). There is also a lower likelihood of migration (6B) and of working in lowerwage establishments (4B) among late leavers. As suggested by our hypothesis, this could partly be due to selection effects as the most productive (and entrepreneurial) workers are looking for new options long before the closures, while workers staying to the end have fewer options. Descriptives in Table 3 (Appendix) show that there are also higher concentrations of late leavers in small regions and large regional centres compared to metropolitan regions where the number of local opportunities is higher. Moreover, late leavers tend to be older than early leavers as well as non-exit leavers. This last indication could to some extent be explained by Swedish labour market policies, where more establishment experience is often counted as an advantage in redundancy negotiations according to the 'last in-first to go' principle.

Figure 3 offers a closer look at the outcomes over time and describes the shares of redundant workers in different outcomes split by the year in which they exit, in reference to the closedown year. The empirical pattern reinforces the conclusion about the negative bias in the outcomes of workers leaving the closing establishments in the closing year. Up until the final year of the plant, 


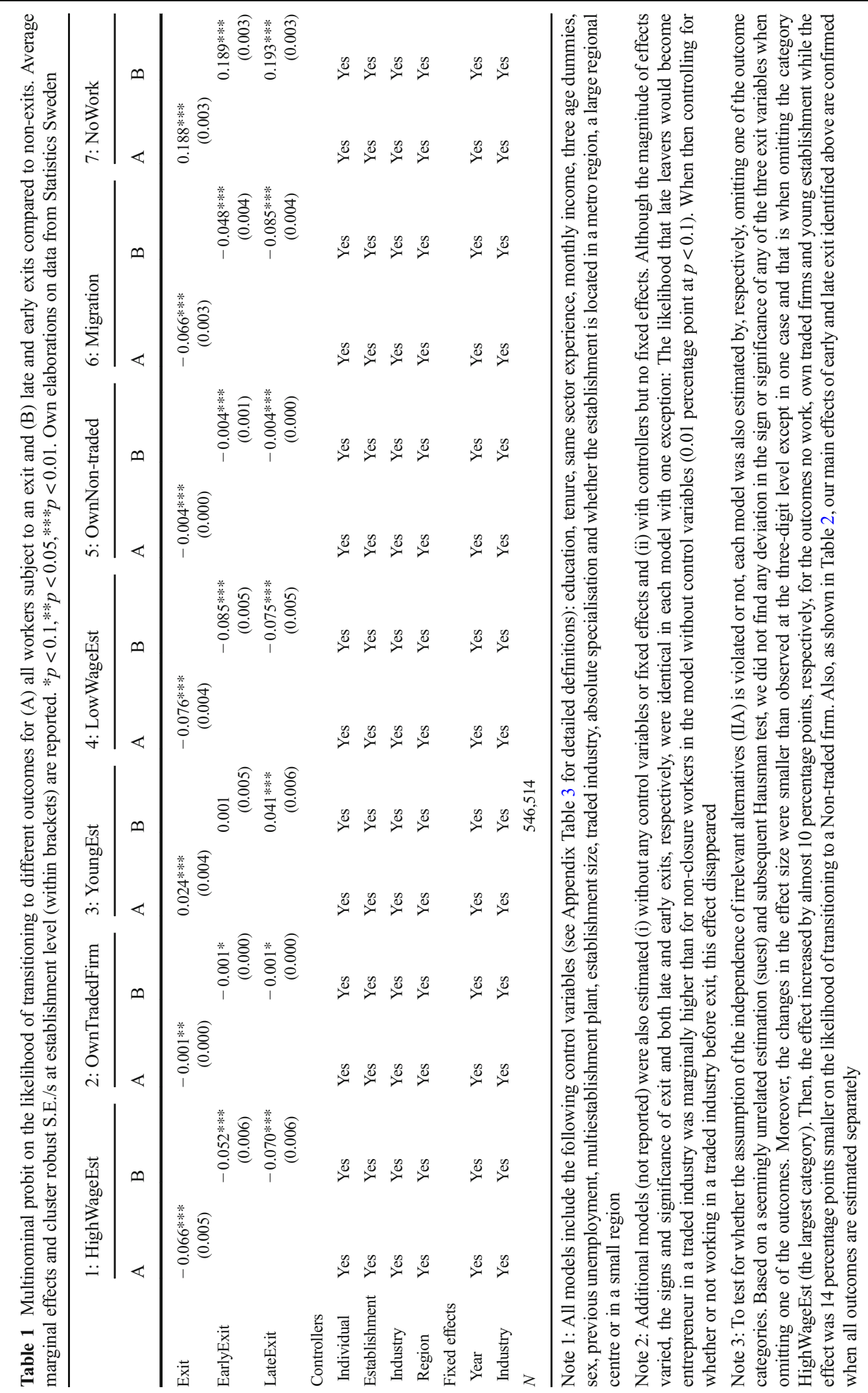


the creative outcomes actually tend to rise for each cohort. The share of workers moving to a higher-wage establishment increases moving from $\mathrm{t}-5$ to $\mathrm{t}-2$, but subsequently decreases in $\mathrm{t}-1$ and $\mathrm{t} 0$. The share of workers moving to young establishments increases substantially from $\mathrm{t}-4$ to $\mathrm{t}-1$ while the share of workers migrating regionally, going to less productive establishments or becoming entrepreneurs in either traded or non-traded industries, is fairly stable over time. Most notable, again, is that the share of workers out of work increases dramatically in the cohort of workers who stay until the final closure.

Creative outcomes are also more common in the metropolitan regions than in other regions of the country. While the metropolitan regions (Fig. 3b) show high shares of destructive outcomes as well, they have higher shares of participation in more productive establishments and young establishments and lower shares of migration than large regional centres (Fig. 3c) and other small regions (Fig. 3d). Differences in the rate of entrepreneurship and being out of work are however negligible across regions.

\subsection{The role of experience and human capital}

To address our second hypothesis and investigate to what extent different forms of human capital and experience may influence the likelihood for redundant workers to induce creative changes in the region, we turn to linear probability models estimated on each outcome. These are essentially OLS-models on a binary dependent variable (see Wooldridge 2002 and Mood 2010). The main rationale for using this type of model is that it allows for interactions when computing average marginal effects. Hence, we can use the same sample of matched workers and still highlight the effect of human capital for workers subject to an exit instead of calculating the average effect for the entire sample. While the models accounted for in Table 2 in general confirm our findings from the multinominal probit models (Table 1) by showing that workers subject to an exit are less likely to trigger creative changes than non-closure workers, some additional findings are worth highlighting related to our second hypothesis.

First, according to the estimates on the variables on human capital without interactions, we find that highly educated workers (with at least a bachelor's degree) are somewhat more likely to participate in creative entrepreneurial efforts $(0.3 \%$, model 2$)$ and avoid unemployment $(-0.3 \%$, model 7$)$, but they are more likely to migrate (5\%, model 6). Tenure increases not only in the likelihood of going to high-income establishments (1\%, model 1) and young establishments (4\%, model 3 ), but also in becoming engaged in creative entrepreneurial activities $(0.2 \%$, model 2$)$. However, it seems that the importance of experience among workers not subject to an exit has more to do with advantages from time spent in the same establishment (tenure) rather than in the industry as same sector experience does not influence creative changes.

Second, concerning the role of human capital for both early and late exits, our findings suggest that education on the one hand has a negligible role for the outcome of these two groups compared to the matched sample, while it on the other hand reduces the risk of unemployment for both groups of workers. However, it is instead income that has a greater role as high-income earners among both early and late exits are somewhat more likely to become re-employed in incumbent establishments (both high and low wage establishments) $(0.1 \%$, model 1 and 0.2 to $0.3 \%$, model 4$)$ and in young establishments $(0.1$ to $0.2 \%$, model 3$)$, and they are less likely to be unemployed $(-0.5 \%$, model 7$)$. Highincome earners are also somewhat more likely to leave the region $(0.1 \%$, model 6$)$ if they are early leavers, which correspond to the idea that they have the resources to early on adapt to potential changes in their environment. Our evidence does not suggest that highly educated individuals are more likely to start up a new business when exiting (early or late) from a closing plant. This effect is rather attributed to workers not subject to a closure. ${ }^{7}$ However, in concordance with the matched sample, we do find that experience (tenure) increases the probability of becoming employed in a young establishment or becoming engaged in entrepreneurial activities in non-traded industries.

\footnotetext{
${ }^{7}$ As a robustness check, we estimated these models with a full set of interactions with all control variables (not reported). The interactions with human capital reported above remained stable, but results also showed that establishment size is imperative for the growth of young establishments (only significant in model 3 ) and that this is particularly the case for late exits. On the contrary, regional specialization increase chances of finding new employment or starting-up a new firm and reduce the likelihood of migrating. Specialization did however not influence the transition to young establishments. These findings were similar for both exit and non-exit workers, hence showing the generic role of specialization.
} 
a) All regions

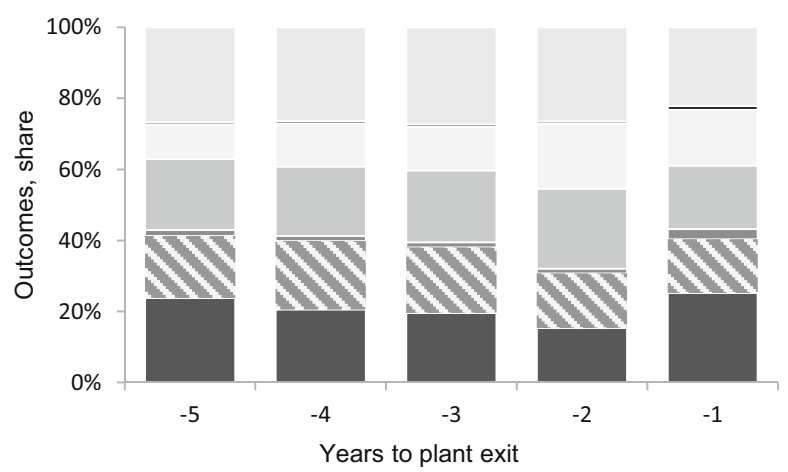

c) Large regions

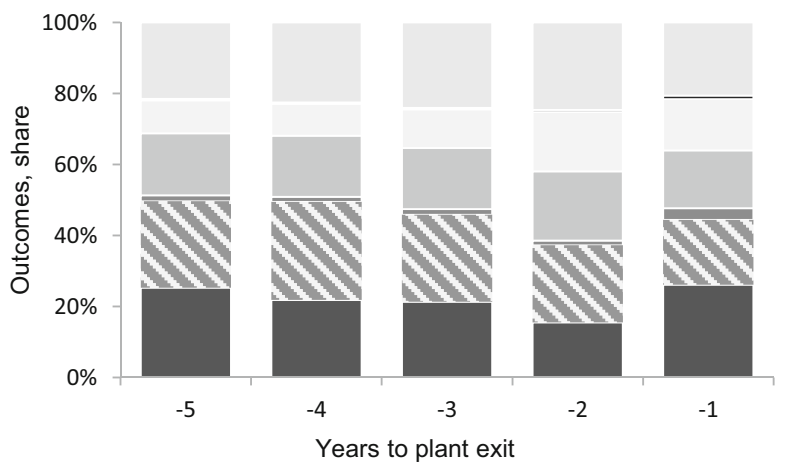

b) Metropolitan regions

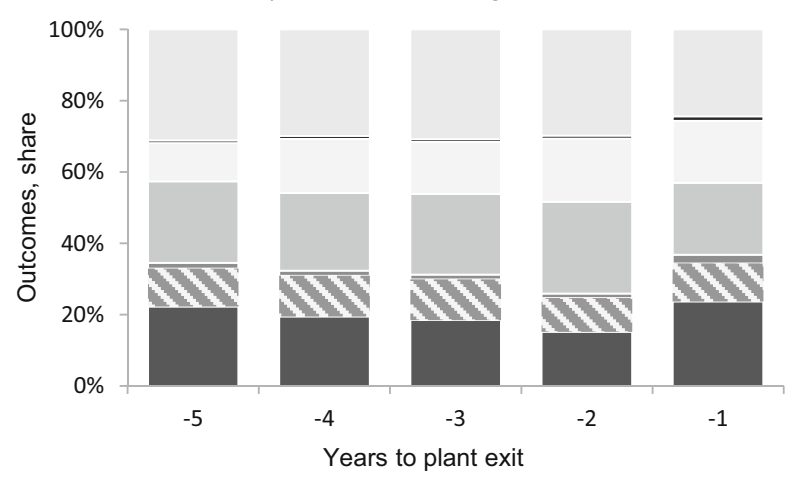

d) Small regions

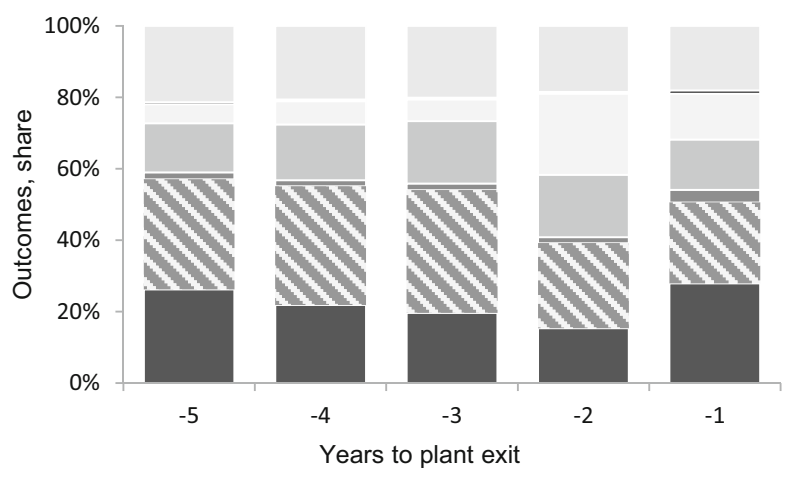

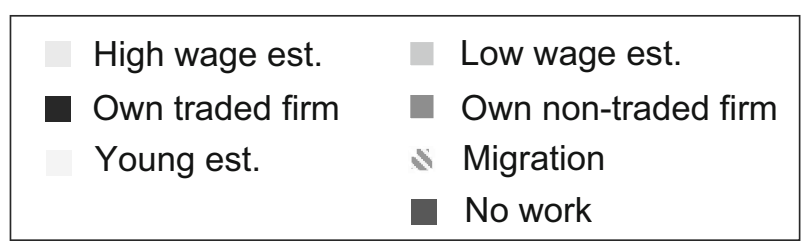

Fig. 3 Outcomes depending on time of exit. Own elaborations on data from Statistics Sweden. a All regions. b Metropolitan regions. c Large regions. d Small regions

Taken together, these findings provide some support for our second hypothesis as we find evidence that young establishments (and entrepreneurial efforts in non-traded industries) can acquire experience from declining activities. Also, the interaction effects suggest that the role of different types of human capital is of greater importance among the late leavers than the early leavers. Apart from the fact that tenure increase the likelihood of employment in young establishments $(0.2 \%$, model 2$)$ and entrepreneurial efforts in non-traded industries $(0.6 \%$, model 5$)$ among late exits, education increases the likelihood of at least becoming re-employed in lower-wage establishments (2.4\%, model 4) for the workers who exit late. This latter finding can be contrasted to the control group for which education decreases the likelihood of entering employment in low-wage establishments.

\subsection{Reallocation of labour and long-term regional change}

Finally, to investigate if the outcomes we termed as creative really are associated with long-run positive change in regions, Fig. 4 plots the balance in regions between shares of outcomes defined as creative destruction (outcomes 1-3) and less creative destruction (outcomes 4-7) against the 10-year employment growth of the region. In general, higher shares of creative outcomes are associated with higher aggregate regional growth. While the metropolitan regions and many of the large regions are located in the upper right of the plot, the lower left is completely dominated by, arguably, less successful smaller regions. Lastly, there are a number of small regional outliers managing to combine high growth with 


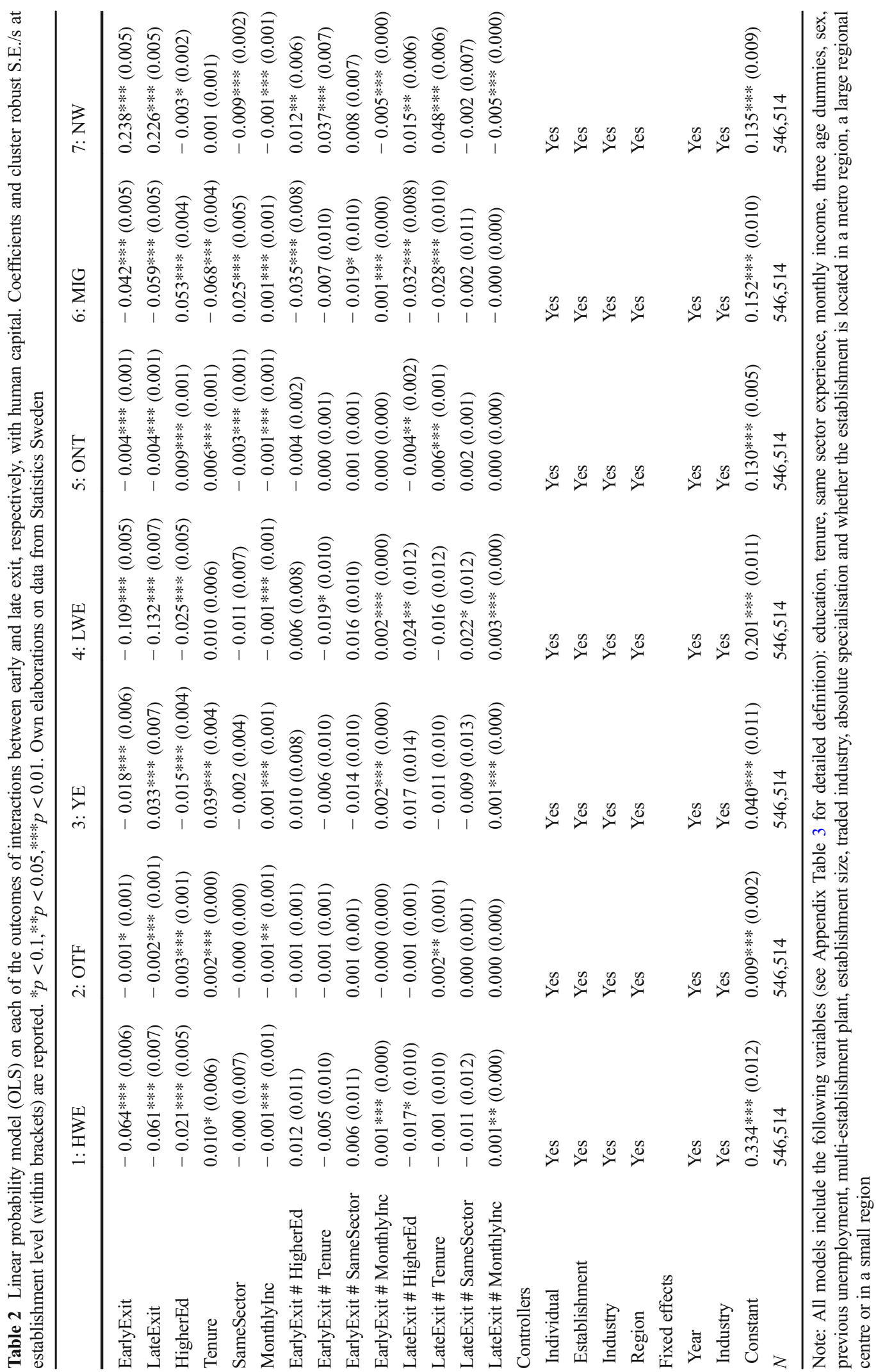




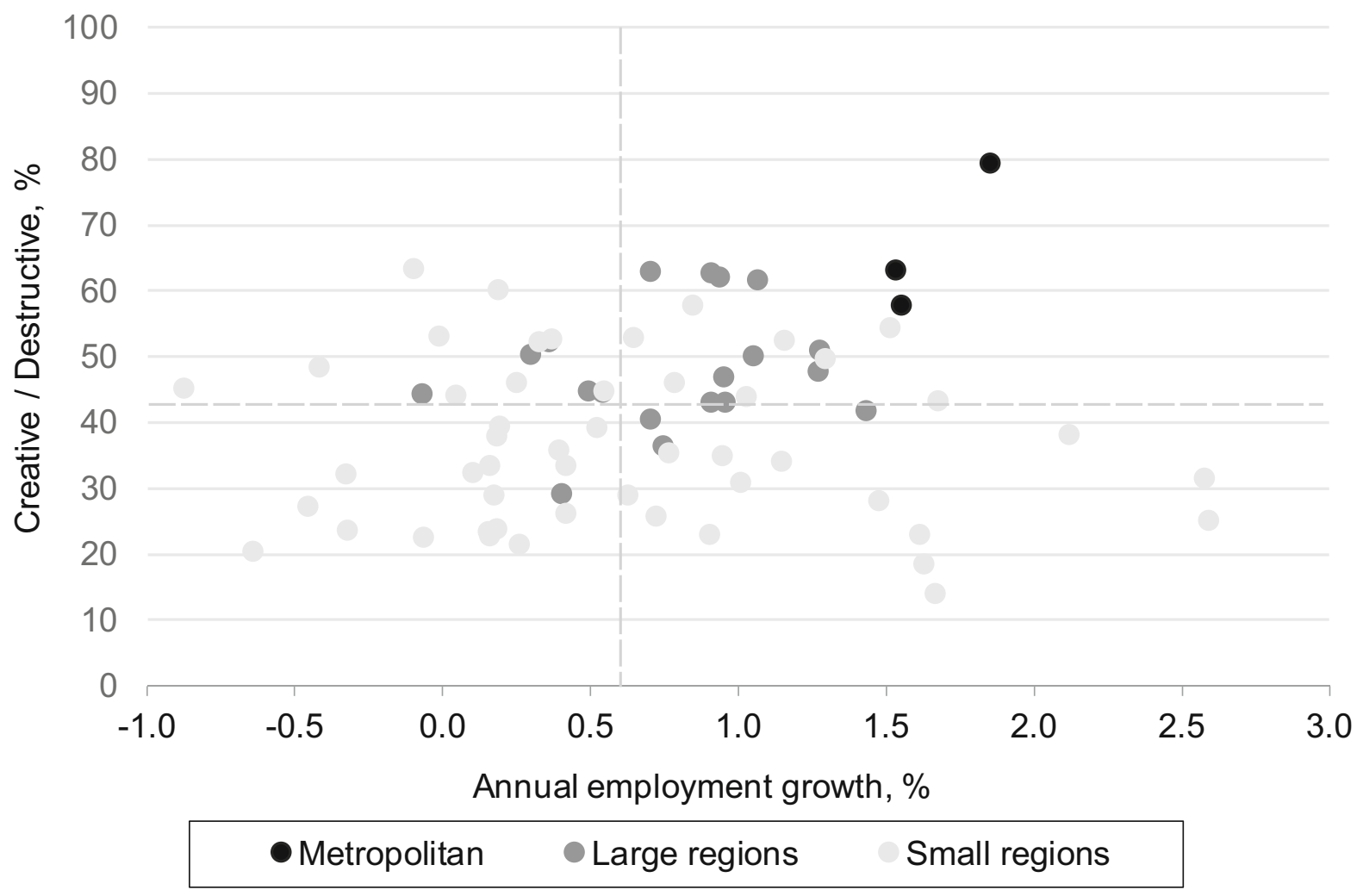

Fig. 4 Correlations between dominance of labour market outcomes and regional development (10-year growth) by region type (markers represent regions, and their colour represents region type). Own elaborations on data from Statistics Sweden

a low share of creative destruction (low right). This is a group of regions where the development has been strongly driven by exogenous factors, such as retail border trade (Strömstad and Haparanda) or booming global demand for mining products (Kiruna, Pajala and Gällivare). They thus constitute exceptions to the transformation pattern that dominates the bulk of regions.

\section{Concluding remarks}

Investigation of our first hypothesis, in which the establishment closure induces creative changes in regions, came with mixed results. In general, our results indicate that redundant workers from closing plants have a lower propensity to participate in outcomes that from a regional point of view can be considered creative. Even if unemployment probabilities are higher among redundant workers, most of them do quickly become employed. However, they tend to do so not only in jobs that are in general less attractive for the individual, as promptly discussed in previous studies, but according to our findings also in activities that are less attractive for the regional economy. In fact, our results suggest that for creation to take place, destruction is not all that important. At least when it comes to redundant labour in the short-term, these are to some extent parallel processes of development.

There are some important qualifications to this result. In our third hypothesis, we conjectured that early leavers are more likely to induce creative changes, compared to late leavers. Indeed, in general, early leavers have slightly higher probabilities of participating in the creative side of transformation and lower probability than late leavers to become unemployed. While this may reflect a selection effect between early and late leavers, it also stresses the need to differentiate the time windows selecting workers affected by establishment closure. Our most striking finding concerns the fact that late leavers are driving the reinforcement of young establishments. Employment in young establishments plays a considerable role in the reallocation process, particularly among those who leave relatively large establishments prior to the year of closure. 
Our findings on which type of workers these establishments hire are more mixed than the findings of, for example, Coad et al. (2014), who show that young and growing establishments need to hire more marginalised groups due to budget constraints. Rather, our results indicate that highincome earners (all workers and workers subject to a closure) and individuals with more experience (non-exit workers) induce such changes.

Even though the average effects do not suggest that destruction feeds significant creation in term of labour outcomes, some groups of workers still have higher probabilities of participating in creative change. In our second hypothesis, we made the conjecture that formal human capital and experience influence the extent to which workers subject to an exit may participate in creative changes such as reinforcement of more productive incumbents or entrepreneurial efforts. While education seems less like a feature influencing the outcomes of redundant workers, it protects from unemployment. Tenure increases the probability of becoming employed not only in young establishments, but also in engaging in entrepreneurial activities among late leavers. Of course, few but experienced employees and entrepreneurs could be extremely important in the long-run since they are likely to participate in the diversification of firms and regions by incorporating previous experiences in their new lines of work. Taken together, these findings provide some evidence that not only young establishments and entrepreneurial ventures acquire experience from declining activities, but they also show the importance of experience and organisational inheritance in entrepreneurial activities (Klepper 2002; Buensdorf and Klepper 2009).
Finally, the regional growth consequences of more or less creative changes after establishment closures were assessed. During the years we investigate, creative destruction tends to be a metropolitan phenomenon. Yet, metropolitan regions also show considerable shares of more destructive outcomes, especially the reinforcement of low income establishments which reflects the overall polarisation trend on the local labour markets. The high rates of migration and entrepreneurial efforts in non-traded industries following redundancies in smaller regions reflect the problems facing these regions in the deindustrialisation process. The local matching of redundant workers and available jobs tends to be suboptimal which results in either migration or activities in the non-traded sector. In that sense, our outcomes are micro-level manifestations of some of the fundamental processes underpinning current trends of regional divergence.

Acknowledgements The research resulting in this article was funded by the Swedish Research Council for Health, Working Life and Welfare (FORTE), project Creative destruction, destructive destruction and labour market dynamics [2013-1313]. We thank Frank Neffke, Guilherme Kenjy Chihaya Da Silva and Einar Holm for comments on earlier drafts, and two anonymous reviewers for constructive comments.

Data availability The individual-level datasets analysed in this study are constructed by Statistics Sweden and made available to researchers by permission from Statistics Sweden only. A fee applies. By law, the authors of this study cannot share the data, but interested researchers must approach Statistics Sweden directly.

\section{Compliance with ethical standards}

Conflict of interest The authors declare that they have no conflict of interest.

\section{Appendix}

Table 3 Definition of variables and descriptives of the matched sample

\begin{tabular}{|c|c|c|c|c|}
\hline \multirow[b]{2}{*}{ Variables } & \multirow[b]{2}{*}{ Definition } & \multicolumn{3}{|l|}{ Share } \\
\hline & & Non-exit & Early exit & Late exit \\
\hline \multicolumn{5}{|l|}{ Dependent variables } \\
\hline $\begin{array}{l}\text { High-wage } \\
\text { establishment }\end{array}$ & $\begin{array}{l}\text { Dummy }=1 \text {, if employed in the same region in } t 1 \text { in establishments with } \\
\text { higher median wage than the establishments they used to work in }\end{array}$ & $32.0 \%$ & $27.1 \%$ & $24.6 \%$ \\
\hline Own traded firm & $\begin{array}{l}\text { Dummy }=1 \text {, if self-employed in firms in traded industries in the region, } \\
\text { which survive at least } 3 \text { years }\end{array}$ & $0.8 \%$ & $0.7 \%$ & $0.9 \%$ \\
\hline Young establishment & $\begin{array}{l}\text { Dummy }=1 \text {, if employed in newly started establishments in the region } \\
\text { (young establishments), which survive at least } 3 \text { years from when the } \\
\text { worker entered the establishment }\end{array}$ & $11.1 \%$ & $11.5 \%$ & $17.2 \%$ \\
\hline
\end{tabular}


Table 3 (continued)

\begin{tabular}{|c|c|c|c|c|}
\hline \multirow[b]{2}{*}{ Variables } & \multirow[b]{2}{*}{ Definition } & \multicolumn{3}{|l|}{ Share } \\
\hline & & Non-exit & Early exit & Late exit \\
\hline $\begin{array}{l}\text { Low wage } \\
\text { establishment }\end{array}$ & $\begin{array}{l}\text { Dummy }=1 \text {, employed in the same region in } \mathrm{t} 1 \text { but in establishments } \\
\text { with lower median wage than the previous establishments they used } \\
\text { to work in }\end{array}$ & $28.7 \%$ & $20.2 \%$ & $20.6 \%$ \\
\hline $\begin{array}{l}\text { Own non-traded } \\
\text { firm }\end{array}$ & $\begin{array}{l}\text { Dummy }=1 \text {, if self-employed in firms in non-traded industries in the } \\
\text { region, which survive } 3 \text { years or more }\end{array}$ & $1.8 \%$ & $1.6 \%$ & $2.1 \%$ \\
\hline Migration & $\begin{array}{l}\text { Dummy }=1 \text {, if leave the region, and move to a different region (regional } \\
\text { migration) }\end{array}$ & $22.5 \%$ & $18.8 \%$ & $15.3 \%$ \\
\hline \multirow[t]{2}{*}{ No work } & Dummy $=1$, if become and stay unemployed, or go into early retirement & $3.1 \%$ & $20.2 \%$ & $19.3 \%$ \\
\hline & Total & $100 \%$ & $100 \%$ & $100 \%$ \\
\hline Independent variables & & \multicolumn{3}{|c|}{ Mean/share } \\
\hline Exit & Dummy $=1$, if worker leaves an closing establishment & 0 & $47.3 \%$ & $52.7 \%$ \\
\hline EarlyExit & $\begin{array}{l}\text { Dummy }=1 \text {, if worker leaves an closing establishment } 2-5 \text { years prior } \\
\text { to closure }\end{array}$ & 0 & $100 \%$ & 0 \\
\hline LateExit & $\begin{array}{l}\text { Dummy }=1 \text {, if worker leaves a closing establishment at either year before } \\
\text { or the same year as exit. }\end{array}$ & 0 & 0 & $100 \%$ \\
\hline HigherEd & $\begin{array}{l}\text { Dummy }=1 \text {, if worker has at least a Bachelor's degree (3-year university } \\
\text { studies) }\end{array}$ & $10.3 \%$ & $10.7 \%$ & $9.5 \%$ \\
\hline Tenure & Dummy $=1$, if number of years in workplace is 5 years or more & $35.1 \%$ & $27.6 \%$ & $42.3 \%$ \\
\hline SameSector & Dummy $=1$, if number of years in same 4 -digit sector is 5 years or more & $43.5 \%$ & $36.2 \%$ & $47.9 \%$ \\
\hline MonthlyInc & Monthly salary in 10,000 Swedish krona & 2.3 & 2.1 & 2.5 \\
\hline Age2029 (reference) & $\begin{array}{l}\text { Dummy }=1 \text {, if worker is between } 20 \text { and } 29 \text { years when leaving the } \\
\text { closing establishment }\end{array}$ & $31.5 \%$ & $38.1 \%$ & $25.8 \%$ \\
\hline Age3045 & $\begin{array}{l}\text { Dummy }=1 \text {, if worker is between } 30 \text { and } 45 \text { years when leaving the } \\
\text { closing establishment }\end{array}$ & $39.4 \%$ & $39.1 \%$ & $40.2 \%$ \\
\hline Age4660 & $\begin{array}{l}\text { Dummy }=1 \text {, if worker is between } 46 \text { and } 60 \text { years when leaving the } \\
\text { closing establishment }\end{array}$ & $29.1 \%$ & $22.8 \%$ & $34.0 \%$ \\
\hline Female & Dummy $=1$, if female & $43.8 \%$ & $46.8 \%$ & $43.1 \%$ \\
\hline PrevUnemp & Dummy $=1$, if having previous experience of unemployment & $11.8 \%$ & $14.1 \%$ & $10.0 \%$ \\
\hline EstablishmentSize & $\begin{array}{l}\text { Number of employees in workplace the year prior to worker leaving } \\
\text { the establishment }(100: \mathrm{s})\end{array}$ & 3.1 & 1.8 & 1.5 \\
\hline MultiEstablishment & $\begin{array}{l}\text { Dummy }=1 \text {, if establishment belong to a firm with more than one } \\
\text { establishment }\end{array}$ & $59.1 \%$ & $57.1 \%$ & $49.7 \%$ \\
\hline Traded & Dummy $=1$, if establishment belongs to a traded sector & $30.8 \%$ & $28.5 \%$ & $31.9 \%$ \\
\hline AbsSpec & $\begin{array}{l}\text { Absolute regional (FA-region) number of establishments in the same } \\
\text { 4-digit sector (100:s) }\end{array}$ & 5.32 & 5.91 & 5.49 \\
\hline Metro (reference) & $\begin{array}{l}\text { Dummy }=1 \text {, if workplace is located in a metropolitan labour market } \\
\text { (Stockholm, Gothenburg or Malmö) }\end{array}$ & $54.0 \%$ & $55.3 \%$ & $51.7 \%$ \\
\hline LargeRegC & Dummy $=1$, if workplace is located in a large regional centre & $32.7 \%$ & $32.4 \%$ & $34.0 \%$ \\
\hline SmallReg & Dummy $=1$, if workplace is located in a smaller region & $13.2 \%$ & $12.4 \%$ & $14.3 \%$ \\
\hline
\end{tabular}

Open Access This article is distributed under the terms of the Creative Commons Attribution 4.0 International License (http:// creativecommons.org/licenses/by/4.0/), which permits unrestricted use, distribution, and reproduction in any medium, provided you give appropriate credit to the original author(s) and the source, provide a link to the Creative Commons license, and indicate if changes were made.

\section{References}

Acs, Z., \& Armington, C. (2006). Entrepreneurship, geography, and American economic growth. Cambridge: Cambridge University Press.

Almus, M. (2004). The shadow of death—an empirical analysis of the pre-exit performance of new German firms. Small Business Economics, 23(3), 189-201. 
Armington, C., \& Acs, Z. (2002). The determinants of regional variation in new firm formation. Regional Studies, 36(1), 33-45.

Audretsch, D. B., Dohse, D., \& Niebuhr, A. (2015). Regional unemployment structure and new firm formation. Papers in Regional Science, 94(1), 115-138.

Austin, P. C. (2007). The performance of different propensity score methods for estimating marginal odds ratios. Statistics in Medicine, 26, 3078-3094.

Austin P. C. (2011) An introduction to propensity score methods for reducing the effects of confunding in observational studies. Multivariate Behaviroal Reseach, 46, pp 399-424.

Bailey, D., Chapain, C., \& de Ruyter, A. (2012). Employment outcomes and plant closure in a post-industrial city: an analysis of the labour market status of MG Rover workers three years on. Urban Studies, 49(7), 1595-1612.

Bates, T. (1991). Commercial bank financing of white and black owned small business start-ups. Quarterly Review of Economics and Business, 13, 64-80.

Bathelt, H., \& Boggs, J. S. (2003). Toward a reconceptualization of regional development paths: is Leipzig's media cluster a continuation of or a rupture with the past? Economic Geography, 79(3), 265-293.

Borggren, J., Eriksson, R., \& Lindgren, U. (2016). Knowledge flows in high-impact firms: how does relatedness influence survival, acquisition and exit? Journal of Economic Geography, 16(3), 637-665.

Boschma, R. (2015). Towards an evolutionary perspective on regional resilience. Regional Studies, 49(5), 733751.

Boschma, R., \& Frenken, K. (2011). Technological relatedness and regional branching. In H. Bathelt, M. P. Feldman, \& D. F. Kogler (Eds.), Beyond territory. Dynamic geographies of knowledge creation, diffusion and innovation (pp. 64-81). London: Routledge.

Boschma, R., \& Martin, R. (2010). The aims and scope of evolutionary economic geography. In R. Boschma \& R. Martin (Eds.), The handbook of evolutionary economic geography (pp. 3-39). Cheltenham: Edward Elgar.

Boschma, R., Minondo, A., \& Navarro, M. (2013). The emergence of new Industries at the Regional Level in Spain: a proximity approach based on product relatedness. Economic Geography, 89(1), 29-51.

Buensdorf, G., \& Klepper, S. (2009). Heritage and agglomeration: the Akron tyre cluster revisited. The Economic Journal, 119, 705-733.

Cameron, A. C., \& Trivedi, P. K. (2010). Microeconometrics using Stata, Revised edition. College Station: Stata Press.

Carrasco, R. (1999). Transitions to and from self-employment in Spain: an empirical analysis. Oxford Bulletin of Economics and Statistics, 61(3), 315-341.

Coad, A., Daunfeldt, S.-O., Johansson, D., \& Wennberg, K. (2014). Whom do high-growth firms hire? Industrial and Corporate Change, 23(1), 293-327.

Eliasson, M., \& Storrie, D. (2006). Lasting or latent scars? Swedish evidence on the long-term effects of job displacement. Journal of Labor Economics, 24(4), 831-856.

Eriksson, R., Otto, A., \& Henning, M. (2016). Industrial and geographical mobility of workers during industry decline: the Swedish and German shipbuilding industries 19702000. Geoforum, 75, 87-98.
Fallick, B. (1996). A review of the recent empirical literature on displaced workers. Industrial and Labor Relations Review, 50(1), 5-16.

Feldstein, M. (2008). Did wages reflect growth in productivity? Journal of Policy Modeling, 30(4), 591-594.

Frederiksen, A., \& Westergaard-Nielsen, N. (2007). Where did they go? Modelling transitions out of jobs. Labour Economics, 14, 811-828.

Frenken, K., Van Oort, F., \& Verburg, T. (2007). Related variety, unrelated variety and regional economic growth. Regional Studies, 41(5), 685-697.

Fritsch, M., \& Falck, O. (2007). New business formation by industry over space and time: a multidimensional analysis. Regional Studies, 41(2), 157-172.

Griliches, Z., \& Ragev, H. (1995). Firm productivity in Israeli industry 1979-1988. Journal of Econometrics, 65, 175-203.

Gripaios, P., \& Gripaios, R. (1994). The impact of defense cutsthe case of redundancy in Plymouth. Geography, 79(342), 32-41.

He, C., Yan, Y., \& Rigby, D. (2016). Regional industrial evolution in China. Papers in Regional Science. https://doi.org/10.1111 /pirs. 12246.

Ho, D. E., Imai, K., King, G., \& Stuart, E. A. (2007). Matching as nonparametric preprocessing for reducing model dependence in parametric causal inference. Political Analysis, 15, 199236.

Hane-Weijman, E., Eriksson, R. H., \& Henning, M. (2017). Returning to work: regional determinants of re-employment after major redundancies. Regional Studies. https://doi. org/10.1080/00343404.2017.1395006.

Holm, J. R., Østergaard, C. R., \& Olesen, T. R. (2016). Destruction and reallocation of skills following large company closures. Journal of Regional Science, 57(2), 245-265.

Huttunen, K., Møen, J., \& Salvanes, K. G. (2006). How destructive is creative destruction? The costs of worker displacement. IZA Discussion Paper Series No. 2316.

Huttunen, K., Møen, J., \& Salvanes, K. (2011). How destructive is creative destruction? Effects of job loss on job mobility, withdrawal and income. Journal of the European Economic Association, 9(5), 840-870.

Jacobson, L., LaLonde, R., \& Sullivan, D. (1993). Earnings losses of displaced workers. The American Economic Review, 83(4), 685-709.

Klepper, S. (2002). The capabilities of new firms and the evolution of the US automobile industry. Industrial and Corporate Change, 11(4), 645-666.

Lee, S., Florida, R., \& Acs, Z. (2004). Creativity and entrepreneurship: a regional analysis of new firm formation. Regional Studies, 38(8), 879-891.

March, J., \& Simon, H. (1958). Organizations. New York: John Wiley and Sons.

Mood, C. (2010). Logistic regression: why we cannot do what we think we can do, and what we can do about it. European Sociological Review, 26(1), 67-82.

Neffke, F., Hartog, M., Boschma, R., \& Henning, M. (2018). Agents of structural change. The role of firms and entrepreneurs in regional diversification. Economic Geography, 94(1), 23-48.

Neffke, F., Henning, M., \& Boschma, R. (2011). How do regions diversify over time? Industry relatedness and the 
development of new growth paths in regions. Economic Geography, 87(3), 237-265.

Neffke, F., Hartog, M., Boschma, R., \& Henning, M. (2014). Agents of structural change. The role of firms and entrepreneurs in regional diversification. Papers in Evolutionary Economic Geography (PEEG) No. 14.10, Utrecht University, Section of Economic Geography.

Neffke, F., Otto, A., \& Hidalgo, C. (2016). The mobility of displaced workers: how the local industry mix affects job search strategies. Papers in Evolutionary Economic Geography (PEEG) No. 16.05, Utrecht University, Section of Economic Geography.

Ohlsson, H., \& Storrie, D. (2012). Long-term effects of public policy for displaced workers in Sweden: shipyard workers in the west and miners in the north. International Journal of Manpower, 33(5), 514-538.

Parker, S. (2009). The economics of entrepreneurship. Cambridge: Cambridge University Press.

Pfann, G. A., \& Hamermesh, D. (2008). Two-sided learning with applications to labor turnover and worker displacement. Jahrbücher für Nationalökonomie und Statistik, 228(5-6), 423-445.

Pike, A. (2005). Building a geographical political economy of closure: the case of R\&DCo in North East England. Antipode, 37(1), 93-115.
Ritsilä, J., \& Tervo, H. (2002). Effects of unemployment on new firm formation: micro-level panel data evidence from Finland. Small Business Economics, 19(1), 31-40.

Schumpeter, J. A. (1934). The theory of economic development: an inquiry into profits, capital, credit, interest and the business cycle. Cambridge: Harvard University Press.

Schumpeter, J. A. (1939). Business cycles: a theoretical, historical, and statistical analysis of the capitalist process. New York: McGraw-Hill Book Company Inc.

Schwerdt, G. (2011). Labor turnover before plant closure: "leaving the sinking ship" vs. "captain throwing ballast overboard". Labour Economics, 18, 93-101.

Sutaria, V., \& Hicks, D. (2004). New firm formation: dynamics and determinants. The Annals of Regional Science, 38(2), 241-262.

Svaleryd, H. (2015). Self-employment and the local business cycle. Small Business Economics, 44(1), 55-70.

Tomaney, J., Pike, A., \& Cornford, J. (1999). Plant closure and the local economy: the case of Swan Hunter on Tyneside. Regional Studies, 33(5), 401-411.

Wooldridge, J. M. (2002). Econometric analyses of cross section and panel data. Cambridge: MIT Press. 